\title{
MEASURING THE YAW MOMENT OF INERTIA
}

OF A VEHICLE

\section{PETR HEJTMÁNEK, ONDŘEJ BLAŤÁK, PAVEL KUČERA, PETR PORTEŠ, JAN VANČURA}

Institute of Automotive Engineering, Brno University of Technology, Technická 2, CZ 61669 Brno, Czech Republic

Tel.: +420 541142 272, Fax: +420 541143 354, E-mai: hejtmanek@fme.vutbr.cz

\section{SHRNUTí}

Článek popisuje postup určení momentu setrvačnosti vozidla ke svislé ose. Je navržen měřicí stav pro měření momentu setrvačnosti založený na principu fyzikálního kyvadla a je analyzován vliv chyby měření periody kmitu na celkovou chybu určení momentu setrvačnosti. $V$ programu Labview je sestaven výpočtový postup pro přesné určení periody kmitavého pohybu z naměřených dat. Funkčnost celého měřicího postupu je ověrena stanovením přesnosti a opakovatelnosti měření.

KLIČCVÁ SLOVA: MOMENT SETRVAČNOSTI VOZIDLA KE SVISLÉ OSE, PERIODA KMITU, FYZIKÁLNÍ KYVADLO

\section{ABSTRACT}

This article sets out a method for the determination of a vehicle's yaw moment of inertia. A test rig for moment of inertia measurements based on the physical pendulum principle has been designed and the effect of the oscillation period measurement error on the total measurement error was analysed. The computational procedure for accurate oscillation period determination was developed in the LabVIEW software environment, and the function of the complete measurement procedure was then verified by evaluating the accuracy and precision of the measurements.

KEYWORDS: VEHICLE YAW MOMENT OF INERTIA, OSCILLATION PERIOD, PHYSICAL PENDULUM

\section{INTRODUCTION}

Knowledge of moment of inertia, obtained either by experimental measurement or computational estimates, is an important factor during the design and construction of all motor vehicles. It is a crucial input for various vehicle mathematical models, and the yaw moment of inertia in particular is an integral part of directional dynamics investigations. These mass properties of a vehicle are also used by the control algorithms of electronic driver assistance systems, such as ESP (electronic stability program). If a sufficiently detailed vehicle model is to be constructed, it is necessary to ensure that it has inputs of adequate accuracy, including moment of inertia values.

Most yaw moment of inertia measurement methods are based on the physical pendulum principle. One such method is the suspension method, presented in detail in Ref. [1-4]. This method uses the oscillating motion of an object (automobile, aircraft, etc.) which is suspended by cables. Various versions of this method are possible using different numbers of cables. The other method uses a torsion pendulum, where the rotational oscillation of an object placed on a rig is achieved using torsional or coil springs. Additional information about this method can be found in $[5,6]$. The relative accuracy of all these approaches varies from $0.3 \%$ to $1 \%[3,5 \& 11]$, and one of the main issues is precise positioning of the vehicle on the device.

The device described here is based on the torsion pendulum principle. The accuracy of acquired moment of inertia is therefore dependent, in particular, on the oscillation period measurement error [7]. This article further presents the procedure for yaw moment of inertia measurement of a vehicle using a test rig and data analysis process, both designed at the Institute of Automotive Engineering of the Faculty of Mechanical Engineering, Brno University of Technology.

\section{TEST RIG DESIGN}

The basic principle for yaw moment of inertia determination is derived from physical pendulum theory. Experimental determination of moment of inertia is performed on a rotational rig which oscillates around the vertical axis, the returning motion provided by coil springs. The formula derived from the physical pendulum moment of inertia determination has the following form [6]: 


$$
I=T^{2} \times \frac{C_{T}}{4 \times \pi^{2}}
$$

Where:

I... yaw mass moment of inertia

$T$...oscillation period

$C_{\mathrm{T}} \ldots$ total torsional stiffness generated by coil springs

This moment of inertia equation describes undamped oscillations, while in the real world the movement is damped by friction. However, this damping can be ignored, as its influence on the oscillation period magnitude is negligible, which is proved further in the article.

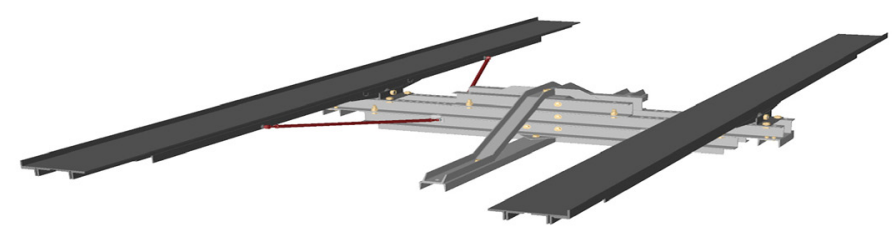

FIGURE 1: Complete rig for measuring a vehicle's yaw moment of inertia OBRÁZEK 1: Kompletní stav pro měření momentu setrvačnosti vozidla

The measurement device consists of two main parts: a static part and a rotational part. The static part is represented by a rigid steel cross attached to a steel base with screws. This steel base is a plate embedded into the laboratory floor, with a weight of 14.5 tonnes, an upper surface of $15 \mathrm{~m}^{2}$ and a flatness of $0.1 \mathrm{~mm}$ - precise horizontal positioning is necessary for high measurement accuracy.

The rotational part including car ramps (dark coloured part in Figure 1) is attached to the static part using low-friction axial bearings, which allow rotation around the vertical axis. Four coil springs, which provide the oscillating motion, are mounted between both parts, two on each side perpendicular to the rotation axis at the distance $l_{i}$. Total torsional stiffness $C_{T}$ generated by coil springs with stiffness $c_{i}$ can therefore be calculated as:

$$
C_{T}=\sum_{i} c_{i} \times l_{i}^{2}
$$

The car ramps not only provide a means for driving on and off the rig - they are also able to rock, so that the vehicle's longitudinal

$$
I_{\mathrm{z}}=I-m \times r^{2}
$$

centre of gravity can be placed in the middle of the ramps. This movement along the lateral axis of the rig is provided by radial ball bearings. After positioning the vehicle appropriately, both ramps are fixed using strut rods.

The main advantages of the designed rig are its simple and rigid construction with low space requirements, and above all its ability to enable isolated oscillations of the vehicle around the desired axis of rotation without the additional unwanted movements that occur when using the suspension method.

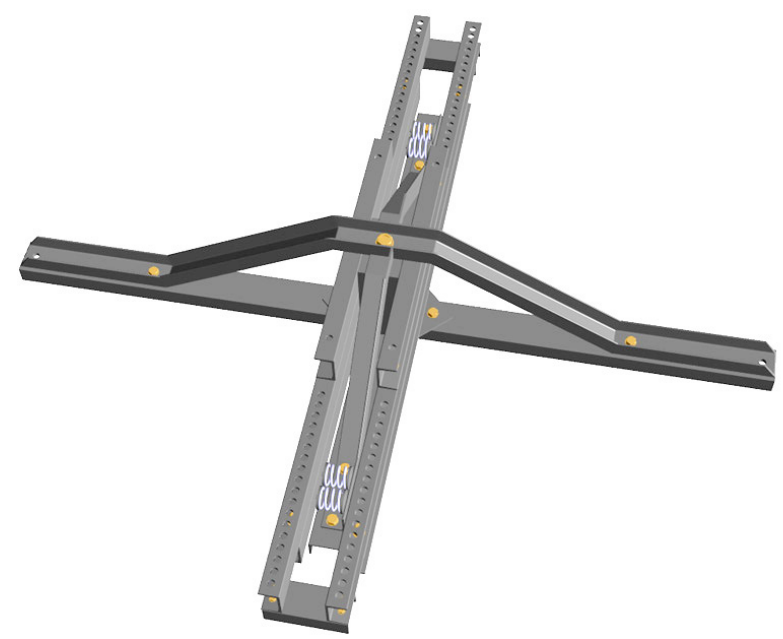

FIGURE 2: Measurement device without ramps to illustrate spring placement OBRÁZEK 2: Měřicí zařízení bez nájezdů se znázorněním umístění pružin

\section{MEASUREMENT PROCEDURE}

In the first step, the vehicle is driven onto the ramps of the test rig and established in equilibrium, but only in the longitudinal direction. The vehicle centre of gravity may be displaced from the rotational axis in the lateral direction. Next, the ramps are fixed using rods and the test rig with the vehicle can start oscillating, and the oscillation period of the system $T_{P V}$ can be measured. After driving the vehicle off the ramps, the device is set into the measuring position again and the oscillation period of the rig without the vehicle $T_{p}$ is measured. Thus the yaw inertia value of the vehicle can be calculated according to following formula:

$$
I=\frac{C_{T}}{4 \times \pi^{2}} \times\left(T_{P V}^{2}-T_{P}^{2}\right)
$$

Finally, to determine the yaw moment of inertia of the vehicle at its centre of gravity it is necessary to identify the distance between the lateral position of the centre of gravity and the longitudinal centre line of vehicle - $r$, and next transform the acquired value using Steiner's theorem: 


\section{MEASUREMENT ERROR ANALYSIS}

The test rig measurement error is determined from the accuracy of the oscillation period measurement. The general equation for the relative error of an indirectly measured characteristic is as follows [7]:

$\xi I\left(x_{1}, x_{2}, \ldots\right)=\frac{\Delta I}{I}=\frac{\sqrt{\left(\frac{\partial \mathrm{I}}{\partial x_{1}} \Delta x_{1}\right)^{2}+\left(\frac{\partial I}{\partial x_{2}} \Delta x_{2}\right)^{2}+\ldots}}{I}$

If $C_{T}$ is a constant taking into account the test rig's properties, the equation for the absolute error of the yaw moment of inertia measurement $\Delta \mathrm{l}$ is:

$$
\Delta I=\sqrt{\left(\frac{\partial\left(\text { const } \times\left(T_{P V}^{2}-T_{P}^{2}\right)\right)}{\partial T_{P V}} \Delta T_{P V}\right)^{2}+\left(\frac{\partial\left(\text { const } \times\left(T_{P V}^{2}-T_{P}^{2}\right)\right)}{\partial T_{P}} \Delta T_{P}\right)^{2}}
$$

Although the absolute error of the oscillation period may vary for different configurations of the test rig, the accuracy of the oscillation period is considered constant. Provided that the rig's oscillation absolute measurement error is the same both with and without the vehicle, the equation can be simplified to:

$$
\Delta I=\sqrt{\left(2 \times \text { const } \times T_{P V} \times \Delta T\right)^{2}+\left(2 \times \text { const } \times T_{P} \times \Delta T\right)^{2}}=2 \times \text { const } \times \Delta T \times \sqrt{T_{P V}^{2}+T_{P}^{2}}
$$

For the relative measurement error, the following equation applies:

$$
\xi I=\frac{2 \times \text { const } \times \Delta T \times \sqrt{T_{P V}^{2}+T_{P}^{2}}}{\operatorname{const} \times\left(T_{P V}^{2}-T_{P}^{2}\right)}=2 \times \Delta T \frac{\sqrt{T_{P V}^{2}+T_{P}^{2}}}{T_{P V}^{2}-T_{P}^{2}}
$$

Tab. 1 illustrates the relationship between the relative error of yaw moment of inertia measurement and the absolute error of oscillation period measurement. Values are calculated for a rig oscillating period of $T_{P V}=1.3256 \mathrm{~s}$ with the vehicle and $T_{P}=0.5324 \mathrm{~s}$ without it.

TABLE 1: The absolute oscillation period error - relative moment of inertia error relationship

TABULKA 1: Vztah absolutní chyby periody kmitání a relativní chyby momentu setrvačnosti

\begin{tabular}{cc}
$\Delta \mathrm{T}[\mathrm{s}]$ & $\xi[\%]$ \\
\hline 0.1 & 19.39 \\
\hline 0.05 & 9.69 \\
\hline 0.01 & 1.94 \\
\hline 0.005 & 0.97 \\
\hline 0.001 & 0.19 \\
\hline 0.0005 & 0.10 \\
\hline 0.0001 & 0.02
\end{tabular}

It was established that the resulting moment of inertia error rises linearly with the oscillation period measurement error, and that to achieve a relative accuracy of vehicle moment of inertia measurement of $2 \%$, it is necessary to measure the period with an error magnitude equal to or less than $0.01 \mathrm{~s}$. A sufficiently accurate method for determining the oscillation period is shown further in the article.

Overall vehicle mass $m$ and the distance $r$ measurement errors are not of high significance, as for a standard automobile the relative deviation between $I_{Z}$ and $I$ does not rise above approximately $0.05 \%$ (the distance $r$ varies from 0 to $0.04 \mathrm{~m}$ ).

\section{OSCILLATION PERIOD DETERMINATION}

As mentioned earlier, the moment of inertia measurement procedure utilizes the physical pendulum principle. The previous chapter demonstrates the importance of accurate measurement 
of the oscillation period. Hence a new sophisticated measurement system for oscillation period determination was developed and designed. This system consists of a data acquisition card NI DAQPad-6015, an angular velocity sensor (integrated into MBOX - 3 accelerometers, 3 angular velocity sensors) and a power supply. The recorded angular velocity signal follows the oscillations and forms the periodic function. The complete data recording and processing software uses the LabVIEW software package from National Instruments. The program structure is divided into three phases: calibration, data recording and data processing.

The calibration phase equalizes the measured signal amplitude symmetrically around the zero value.

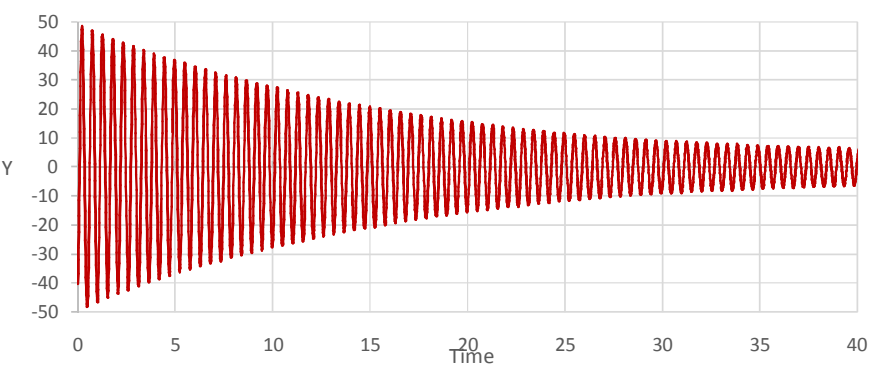

FIGURE 3: The oscillation period measured data - signal from the angular velocity sensor

OBRÁZEK 3: Data z měření periody kmitání - signál snímače úhlové rychlosti

In the data recording phase, data is recorded at a specified sampling rate. The overall measurement time is usually $40 \mathrm{~s}$ and the sampling frequency $100 \mathrm{~Hz}$. The oscillation period changes slightly during the taking of measurements due to the non-linear torsional stiffness of the device (caused by a minor force vector rotation as the coil springs rotate slightly with the movement of the rotational part of the rig).

To evaluate the influence of torsional stiffness non-linearity on the calculation results of the oscillation periods, an analysis of oscillation period change during the recording of angular velocity was performed. Results of this analysis show that the relative deviation of the oscillation period does not rise above $0.5 \%$, which corresponds to a relative error of $1.2 \%$ of the vehicle moment of inertia.

Although the system is damped, as was suggested earlier, the oscillation is considered to be undamped. The damping itself admittedly influences the oscillation period value, but its significance is negligible. According to conducted analysis, the difference of period between damped and undamped motion is less than $0.01 \%$ and the damping coefficient value is approximately $0.03-0.04$.

Using the recorded data, the calculation of the oscillation period using a non-linear regression based on the LevenbergMarquardt (LM) algorithm is performed $[8,9]$. The regression analysis investigates the relationship between the independent variable $X$ (time) and the dependent variable $Y$ (the measured property). The Nonlinear Curve Fit LM is used in the LabVIEW software package for the non-linear regression. The model function is shown here:

$y=\left(A e^{\propto\left(t-t_{0}\right)} \sin \left(2 \frac{\pi}{T}\left(t-t_{0}\right)\right)\right)+y_{0}$

The function includes 5 parameters, and their values must be estimated to start with. This is done with the first analysis of the measured data. The aforementioned parameters are: amplitude $A$, damping coefficient $\alpha$, time offset $t_{0^{\prime}}$ oscillation period $T$ and amplitude offset $y_{0}$ (examples of values recorded for a vehicle: $\left.A=0.221 ; \alpha=-0.035 ; t_{0}=0.861 \mathrm{~s} ; T=1.471 \mathrm{~s} ; y_{0}=0.003\right)$. Another LabVIEW function used is the Hanning Window, which serves for refining the evaluation [10], applying the weight function in the regression. This function with the Hanning Window is shown in Figure 4.

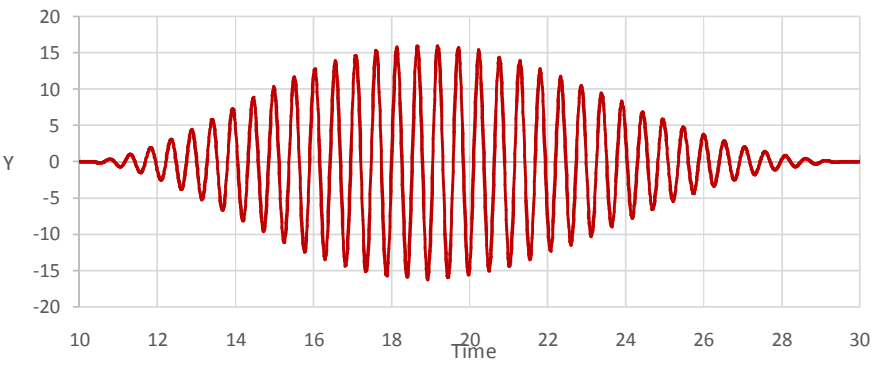

FIGURE 4: The weighting function with the Hanning Window OBRÁZEK 4: Užití váhové funkce Hanningova okna

The algorithm converges to the final result quickly after the computation is started. The best fit parameters are evaluated. Results are shown in Figure 5 (black - measured data, red regression, green - weighting function).

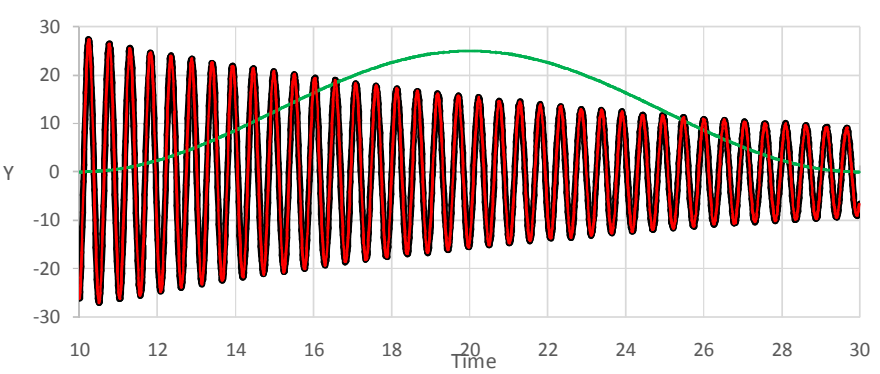

FIGURE 5: Results of angular velocity measurement OBRÁZEK 5: Výsledky měřen úhlové rychlosti

These parameters contain the oscillation period that is used in the next step for the analytical calculation of the moment of inertia. The identification of the resulting yaw moment of 
inertia is based on the steps described above. To obtain the statistical predicative results, it is necessary to conduct the whole procedure (the measurement and the oscillation period determination) repeatedly.

\section{ACCURACY AND PRECISION OF MEASUREMENTS}

The determination of accuracy and precision of the measured data is crucial for each measuring device. Without this knowledge it would be difficult to assess the quality of measured values. Evaluation of measured values (moment of inertia) against the calculated ones is one of the possible methods - in this case it was achieved using lead blocks of known dimensions and weight as a ballast. These blocks are calibrated to a predefined moment of inertia with maximum allowed deviation of $0.7 \%$. Their simple shape ensures that subsequent calculations of inertia will be straightforward. To determine the repeatability it is just necessary to perform the moment of inertia measurements several times.

In the first step, yaw moment of inertia of the rig's rotational parts $I_{P}$ was measured experimentally, reaching the value of $413.06 \mathrm{~kg} \cdot \mathrm{m}^{2}$. Thereafter, lead bricks were placed at each corner of the rig (Figure 7), making the ballast's centre of gravity intersect the rig's vertical rotation axis. The position of each cube was measured and noted. The measurement was repeated five times, the results of which are presented in Table 2, with the ballast's yaw moment of inertia denoted as $I_{V}$.

The corresponding calculation was carried out using the $C A D$ software Pro/Engineer (Figure 6). Bricks were modelled and placed in accordance with the experiment; the ballast's moment of inertia value can then be calculated from the dimensions, volume, density and spatial distribution of all lead bricks. A comparison of measured and calculated values is presented in Table 3.

TABLE 2: The results of the repeated measurements of the ballast's yaw moment of inertia

TABULKA 2: Výsledky opakovaného měření momentu setrvačnosti zátěže

\begin{tabular}{ccccc}
$\begin{array}{c}\text { Measurement } \\
\text { number }\end{array}$ & $\begin{array}{c}I_{P}+I_{V} \\
{\left[\mathrm{~kg} \cdot \mathrm{m}^{2}\right]}\end{array}$ & $\begin{array}{c}I_{V} \\
{\left[\mathrm{~kg} \cdot \mathrm{m}^{2}\right]}\end{array}$ & $\begin{array}{c}\Delta I_{V} \\
{\left[\mathrm{~kg} \cdot \mathrm{m}^{2}\right]}\end{array}$ & $\begin{array}{c}\left|\delta I_{V}\right| \\
{[-]}\end{array}$ \\
\hline 1 & 2718.86 & 2305.80 & 0.60 & $0.03 \%$ \\
\hline 2 & 2719.01 & 2305.5 & 0.75 & $0.03 \%$ \\
\hline 3 & 2718.62 & 2305.56 & 0.37 & $0.02 \%$ \\
\hline 4 & 2718.18 & 2305.12 & -0.08 & $0.00 \%$ \\
\hline 5 & 2716.62 & 2303.56 & -1.64 & $0.07 \%$ \\
\hline average & - & 2305.19 & - & -
\end{tabular}

FIGURE 7: Detailed photo showing the location of quarters of the bricks
OBRÁzEK 7: Detailní fotografie zobrazující umístění jedné čtvrtiny kostek

$\operatorname{RSD}\left(I_{v}\right)=\frac{\sqrt{\frac{1}{n} \sum_{\mathrm{i}} \Delta I_{v}^{2}}}{\bar{I}_{v}}=0.04 \%$

TABLE 3: Moment of inertia - experiment vs. CAD model comparison TABULKA 3: Moment setrvačnosti - srovnání měření a CAD modelu

\begin{tabular}{cccc} 
& $\begin{array}{c}I_{V}-\text { measured } \\
{\left[\mathrm{kg} \cdot \mathrm{m}^{2}\right]}\end{array}$ & $\begin{array}{c}I_{V}-\mathrm{CAD} \\
{\left[\mathrm{kg} \cdot \mathrm{m}^{2}\right]}\end{array}$ & relative error \\
\hline value & 2305.19 & 2283.85 & $0.93 \%$ \\
\hline
\end{tabular}

The results obtained show that the accuracy and precision of the proposed device for the moment of inertia measurement are reasonably high. Based on the performed experiments, the error of the measurement - accuracy is less than $1 \%$ and the RSD (relative standard deviation) - precision is no higher than $0.04 \%$.

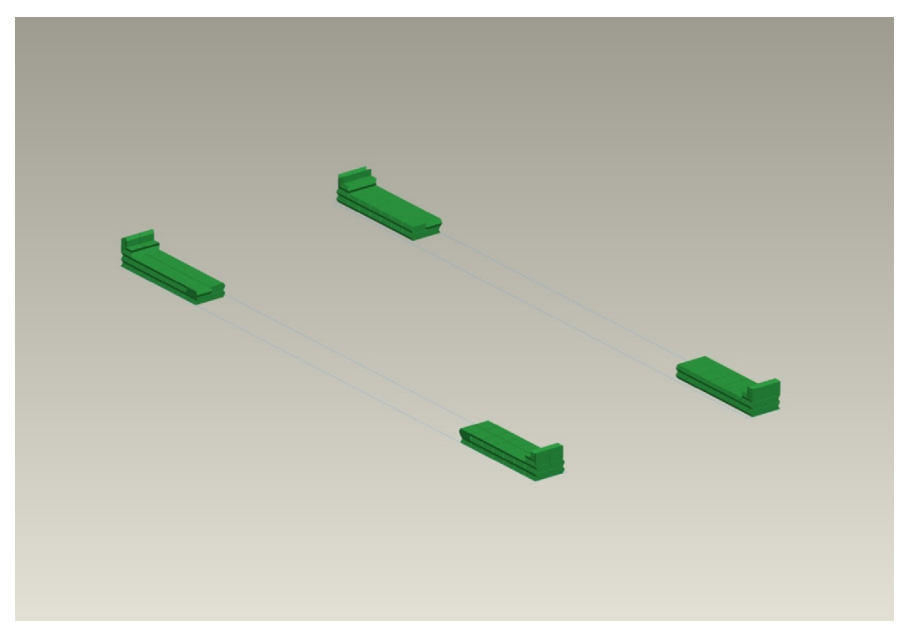

FIGURE 6: CAD model of the measured ballast OBRÁZEK 6: CAD model měřeného závaží

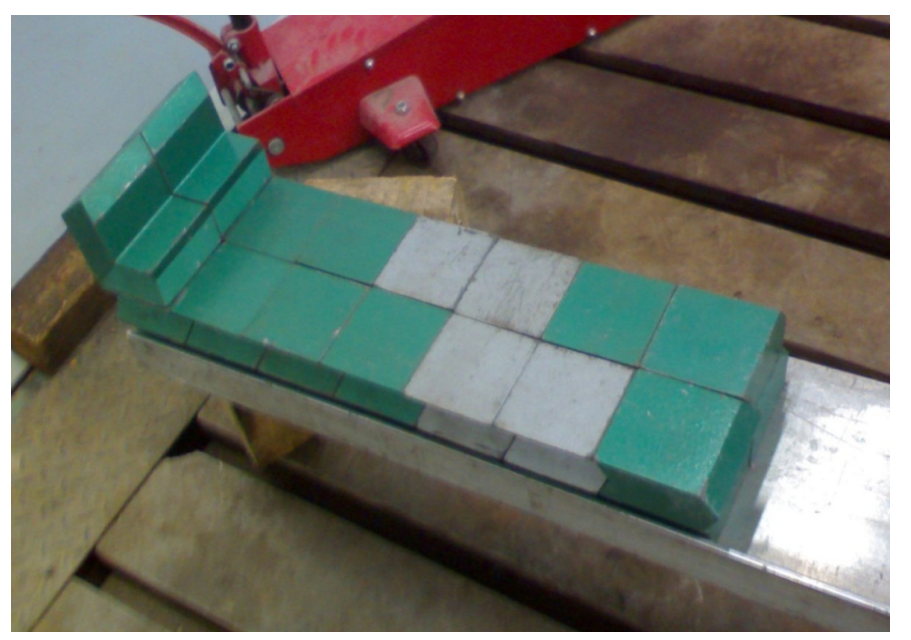


TABLE 4: The vehicle yaw moment of inertia measurement passenger car ( $\mathrm{C}$-segment)

TABULKA 4: Měření momentu setrvačnosti vozidla osobní automobile (třídy C)

\begin{tabular}{ccccc}
$\begin{array}{c}\text { Measurement } \\
\text { number }\end{array}$ & $\begin{array}{c}I_{P}+I_{V} \\
{\left[\mathrm{~kg} \cdot \mathrm{m}^{2}\right]}\end{array}$ & $\begin{array}{c}I_{V} \\
{\left[\mathrm{~kg} \cdot \mathrm{m}^{2}\right]}\end{array}$ & $\begin{array}{c}\Delta I_{V} \\
{\left[\mathrm{~kg} \cdot \mathrm{m}^{2}\right]}\end{array}$ & $\begin{array}{c}\left|\delta I_{V}\right| \\
{[-]}\end{array}$ \\
\hline 1 & 2915.94 & 2512.44 & 2.29 & $0.09 \%$ \\
\hline 2 & 2916.32 & 2512.82 & 2.67 & $0.11 \%$ \\
\hline 3 & 2921.72 & 2518.22 & 8.07 & $0.32 \%$ \\
\hline 4 & 2899.66 & 2496.16 & -13.99 & $0.56 \%$ \\
\hline 5 & 2914.99 & 2511.49 & 1.35 & $0.05 \%$ \\
\hline 6 & 2914.77 & 2511.27 & 1.12 & $0.04 \%$ \\
\hline 7 & 2911.39 & 2507.89 & -2.25 & $0.09 \%$ \\
\hline 8 & 2914.19 & 2510.69 & 0.55 & $0.02 \%$ \\
\hline 9 & 2915.36 & 2511.86 & 1.71 & $0.07 \%$ \\
\hline 10 & 2912.13 & 2508.63 & -1.51 & $0.06 \%$ \\
\hline average & - & 2510.15 & - & -
\end{tabular}

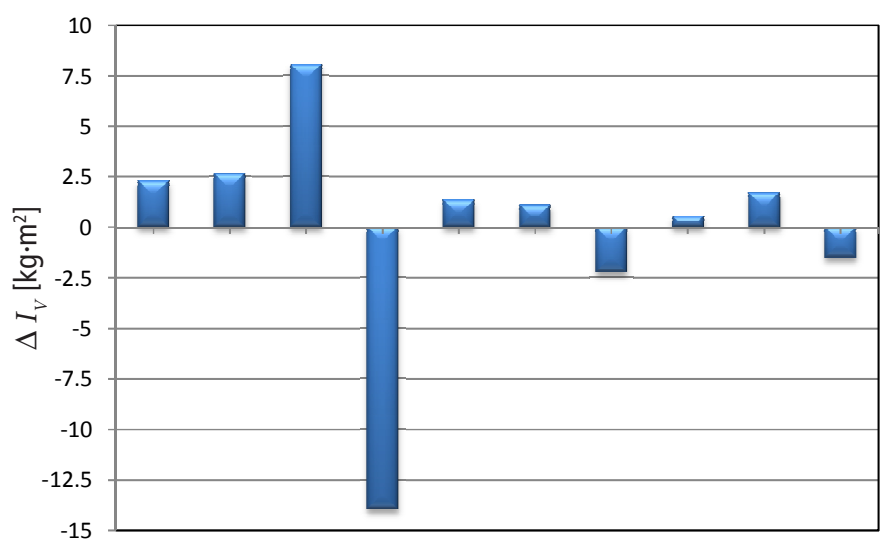

FIGURE 8: The variance of the measured vehicle yaw moment of inertia OBRÁZEK 8: Rozdíl měřeného momentu setrvačnosti vozidla

The next experiment was targeted at analysing the precision of actual passenger car measurements. The vehicle yaw moment of inertia measurement was carried out on a small family car (C-segment) with a weight of $1350 \mathrm{~kg}$. The vehicle configuration for the measurement included: no passengers, no luggage or ballast, fully filled fuel tank. Tyres were inflated to a pressure that is higher than the value recommended by the manufacturer with the aim of avoiding excessive deformation of the tires during the measurement. Additional movements of sprung parts of the vehicle during oscillations, which could have an adverse effect on the measurement, are suppressed by tying the vehicle's side sills up to the ramps. In the period between ballast and vehicle measurements, the rig was slightly modified, which reduced its moment of inertia value to $403.5 \mathrm{~kg} \cdot \mathrm{m}^{2}$. The vehicle moment of inertia was measured only relative to the centre of the rig and was not transformed into the vehicle's centre of gravity. Complete results of the vehicle measurements are presented in Table 4.

Although the RSD of the measurement has risen to $0.2 \%$, the device can still be considered very precise. Evaluation with calculated (theoretical) values was not possible as relevant CAD data of the vehicle are not available, and even if they were, they would not include service fluids and other factors, which have an impact on the experimentally determined yaw moment of inertia. For these reasons, the relative accuracy of the vehicle yaw moment of inertia measurement cannot be accurately deduced from the presented experimental series.

\section{CONCLUSION}

This article covers several steps in the construction of a test rig for measurement of vehicle moment of inertia. The moment of inertia measurement error has been analysed and its close relationship with the oscillation period accuracy was established. The demand for accurate oscillation period determination was satisfied by developing an algorithm in the LabVIEW software environment.

The accuracy and precision of measurement was evaluated in two steps: first by comparing measurements and calculations of lead bricks serving as ballast, with resulting relative error $<1 \%$ and relative standard deviation of $0.04 \%$, and secondly by measuring a C-segment vehicle, which has shown an RSD of $0.2 \%$. The relative error of vehicle measurement was not determined; nevertheless, the error of vehicle measurement can be derived from validation of lead bricks. The accuracy value given by the measurement of the ballast corresponds to the references cited.

The main improvement of this approach over other designs is that the precise positioning of the vehicle can be achieved in only a few minutes using the vehicle's own drive (no crane or other equipment needed). Some elementary parameters of the device can be easily changed with respect to the measured vehicle size, such as torsional stiffness of the rig or ramp distance for given wheel track.

Further work will be aimed at improving the test rig design by incorporating the ability to measure roll and pitch moment of inertia.

\section{ACKNOWLEDGEMENTS}

Published results have been achieved with the help of "Modelling of vehicle dynamics" project, registration No. FSI-J-12-1803, granted by specific university research of Brno University of Technology. This support is gratefully acknowledged. 
LIST OF ABBREVIATIONS AND SYMBOLS

angular velocity amplitude $\left[\mathrm{rad} \cdot \mathrm{s}^{-1}\right]$

$c_{i} \quad$ linear stiffness of coil spring $\mathrm{i}\left[\mathrm{N} \cdot \mathrm{m}^{-1}\right]$

$C_{T} \quad$ torsional stiffness $\left[\mathrm{N} \cdot \mathrm{m} \cdot \mathrm{rad}^{-1}\right]$

I moment of inertia about a general axis $\left[\mathrm{kg} \cdot \mathrm{m}^{2}\right]$

$I_{p} \quad$ measurement stand yaw moment of inertia $\left[\mathrm{kg} \cdot \mathrm{m}^{2}\right]$

$I_{V} \quad$ vehicle (ballast) yaw moment of inertia $\left[\mathrm{kg} \cdot \mathrm{m}^{2}\right]$

$I_{z} \quad$ yaw moment of inertia about the vehicle $\mathrm{z}$ axis $\left[\mathrm{kg} \cdot \mathrm{m}^{2}\right]$

$l_{i} \quad$ perpendicular distance of spring i from rotation axis [m]

$m$ vehicle weight $[\mathrm{kg}]$

$r \quad$ lateral position of the centre of gravity [m]

$T \quad$ oscillation period [s]

$T_{p} \quad$ oscillation period of stand $[\mathrm{s}]$

$T_{P V} \quad$ oscillation period of stand with vehicle [s]

$t_{0} \quad$ time offset [s]

$y_{0} \quad$ angular velocity amplitude offset $\left[\mathrm{rad} \cdot \mathrm{s}^{-1}\right]$

$\Delta I \quad$ yaw moment of inertia absolute measurement error $\left[\mathrm{kg} \cdot \mathrm{m}^{2}\right]$

$\Delta I_{V} \quad$ yaw moment of inertia absolute deviation $\left[\mathrm{kg} \cdot \mathrm{m}^{2}\right]$

$\Delta T \quad$ oscillation period absolute error [s]

$\alpha \quad$ oscillation damping coefficient

$\delta I_{V} \quad$ yaw moment of inertia relative deviation [\%]

$\xi I \quad$ yaw moment of inertia relative measurement error [\%]

\section{REFERENCES}

[1] Woodfield, A. A. (1969). Measurement of the yawing moment and product of inertia of an aircraft by the single point suspension method: theory and rig design. Reports and memoranda (Aeronautical Research Council (Great Britain)), No. 3607.

[2] Crede, C. E. (1948). Determining Moment of Inertia, Machine Design, August, pp. 138.

[3] Jardin, M. R., Mueller, E. R. (2009). Optimized Measurements of Unmanned-Air-Vehicle Mass Moment of Inertia with a Bifilar Pendulum. Journal of Aircraft, Vol. 46, No. 3, May-June, pp. 163-775.

[4] Miller, M. P. (1930). An Accurate Method of Measuring the Moments of Inertia of Airplanes, NACA TN-351

[5] Heydinger, G. J., Durisek, N. J., Coovert, D. A., Guenther, D. A., Novak, S. J. (1995). The Design of a Vehicle Ineria Measurement Facility, SAE, Detroit.

[6] Vlk, F. (2003). Automobilová technická príručka - Zkoušení a diagnostika motorových vozidel, VLK, Brno, ISBN 80-238-9681-4.

[7] Volejník, P. (2006). Návrh měricího zařízení pro určení momentů setrvačnosti. Diploma Thesis, Brno: Vysoké učení technické v Brně, Fakulta strojního inženýrství, pp. 108

[8] Levenberg, K. (1944). A Method for the Solution of Certain Problems in Least Squares, Quart. Appl. Math. Vol. 2, pp. 164-168.

[9] Marquardt, D. (1963). An Algorithm for Least-Squares Estimation of Nonlinear Parameters, SIAM J. Appl. Math. Vol. 11, pp. 431-441.

[10] Oppenheim, A. V., Schafer, R. W. (1989). Discrete-Time Signal Processing, Prentice-Hall, pp. 447-448.

[11] Previati, G., Gobbi, M., Mastinu, M. (2008). Sviluppi nella misura del tensore di inerzia e del baricentro dei corpi rigidi, XXXVII Convegno Nazionale, Universita di Roma. 